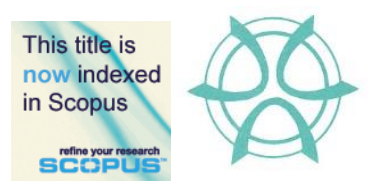

PLANNING MALAYSIA:

Journal of the Malaysian Institute of Planners

VOLUME 17 ISSUE 1 (2019), Page 232 - 239

\title{
SUSTAINABLE BUSINESS LOCATION CHARACTERISTICS OF PURPOSE-BUILT OFFICES IN MALAYSIA
}

\author{
Heng Jia Yun ${ }^{1}$, Edie Ezwan Mohd Safian² \& Ahmad Kaseri Ramin ${ }^{3}$ \\ ${ }^{1,2,3}$ Faculty of Technology Management and Business \\ UNIVERSITI TUN HUSSEIN ONN MALAYSIA
}

\begin{abstract}
The location evaluation of purpose-built office (PBO) has increase in complexity with the addition of sustainability dimension in the evaluation. There are many elements that need to be considered in the complex sustainability concept of PBO in terms of location. This paper aims to investigate stakeholders' perceptions towards PBO in the context of sustainable business location in the Golden Triangle of Kuala Lumpur, Malaysia. Data was obtained through questionnaire survey utilising pairwise comparison technique. Analytic Network Process (ANP) analysis was then employed. The findings demonstrated the dependence of each sustainable business location characteristic of PBO based on the perceptions of selected stakeholders.
\end{abstract}

Keyword: Purpose-built office, sustainable business location, analytic network process 
PLANNING MALAYSIA

Journal of the Malaysia Institute of Planners (2019)

\section{INTRODUCTION}

The purpose-built office (PBO) market is expected to remain competitive because it is backed by well-developed transportation infrastructure, for example, ongoing Mass Rapid Transit (MRT) project to enhance the accessibility between the capital of Kuala Lumpur and surrounding areas (C H Williams Talhar \& Wong, 2015). However, slow economy of the country has resulted in oversupply of office space in the market. To remain competitive, PBO location must suit the preferences and needs of the stakeholders. Therefore, in selecting a sustainable business location for office spaces, the preferences and needs of stakeholders act as important indicators to alter their decisions by examining the characteristics of PBO (Adnan, Daud, Ahmad, \& Aziz, 2009).

In the competitive PBO market, there are previous studies which have identified and classified building characteristics of $\mathrm{PBO}$ based on the stakeholders' opinions and views. However, empirical studies on locational characteristics of PBOs from the office market participants' point of views are limited in Malaysia (Safian \& Nawawi, 2012). Moreover, a finite number of location analysis techniques and grading matrix tools have been developed for locational aspect of $\mathrm{PBO}$ preference.

In Malaysia, the conceptual framework of locational characteristics of PBO is still being developed. By gauging the PBO stakeholders' perceptions towards sustainable business locations, it would help in boosting up the PBO market. Thus, the aim of this paper is to investigate the perception of stakeholders towards PBO in the context of sustainable business location in the Golden Triangle of Kuala Lumpur, Malaysia. After studying the stakeholders' perceptions on their needs and preferences towards the locations of PBOs, the weight of dependence of each sustainable business location characteristics for PBOs was determined. The Analytic Network Process (ANP), as a quantitative approach, was implemented to measure the dependence among sustainable business location characteristics and sub-characteristics of PBO in the local context.

\section{STAKEHOLDERS' PERCEPTIONS MEASUREMENT TOWARDS SUSTAINABLE BUSINESS LOCATION CHARACTERISTICS OF PBO}

Decision making is a continuous process in order to satisfy the preferences and needs of decision makers. Since there are many alternatives in location selection, selecting a sustainable business location for a PBO is a complex and challenging decision for an organisation. Thus, the perceptions of stakeholders are essential to obtain the final decision. At different levels of decision-making, it requires a measurement of individuals' needs. Multi-criteria decision making (MCDM) methods can solve the multiple conflicting criteria and a finite set of alternatives in selecting the best sustainable business location for a PBO. 
Heng Jia Yun, Edie Ezwan Mohd Safian \& Ahmad Kaseri Ramin

Sustainable Business Location Characteristics of Purpose-Built Offices in Malaysia

The location evaluation of purpose-built office (PBO) has increase in complexity with the addition of sustainability dimension in the evaluation. The Analytic Network Process (ANP) has been chosen to gauge individuals' preferences and needs in selecting the best sustainable business location for PBO. ANP is the generalized form of AHP (Dong-mei \& Chun-shu, 2011). In ANP model, the decision matrix is no longer linear as AHP. It need not be arrange in a hierarchical structure for the evaluation of criteria. Thus, ANP deals with dependencies (Ishizaka \& Nemery, 2013). If the criteria are correlated, the elements listed are connected to one another.

All the relevant location criteria can be demonstrated and prioritised interdependent influences of each criteria in a network structure in the ANP model. The interrelationship within clusters of elements are allowed in order to overcome the limitation of linear hierarchical structures (Saaty, 2009). ANP model has better reliability, making it applicable in the real world environment (Taslicali \& Ercan, 2006; Saaty, 2009). In this research, by implementing the Fundamental Scale for pairwise comparisons in the ANP analysis, the weight of dependence of each sustainable business location criteria for PBO is determined based on the perceptions of stakeholders.

\section{METHODOLOGY}

Questionnaire-based survey was adopted in the data collection process to investigate the stakeholders' perceptions towards PBO in the context of sustainable business location in Golden Triangle of Kuala Lumpur, Malaysia. Questions included the use the pairwise comparison method in determining the weights of dependence of sustainable business location characteristics for PBOs.

\section{Research Sampling}

Questionnaire survey was administered to occupants of PBO in the study area. This is because they are normally the first-hand users of PBO. Thus, the opinions of the occupants of $\mathrm{PBO}$ are essential in determining the relative dependence of the sustainable business location of PBO.

Selection of respondents involved two-stage cluster sampling. Two-stage cluster sampling is a combination of cluster sampling and simple random sampling method, which aims to identify each element that should represent the heterogeneity of the population (Ahmed, 2009). In the first stage, several main streets within the Golden Triangle of Kuala Lumpur were selected. The main streets were the primary sampling unit at this stage. Therefore, four main streets were selected, which were Jalan Ampang, Jalan Sultan Ismail, Jalan Raja Chulan and Jalan Imbi.

Each PBO along the selected main streets could be chosen randomly in the second stage of sampling. By using simple random sampling method, 5 PBOs for each of the four main streets were selected. This resulted in 19 PBOs were 
selected in the study area. For each PBO, 10 of its occupants were selected to answer the questionnaire survey (Table 1).

Table 1: Survey sample in Golden Triangle Kuala Lumpur

\begin{tabular}{lcc}
\hline & PBOs & Occupants of PBO \\
\hline Sampling Technique & $\begin{array}{c}\text { Probability Sampling: } \\
\text { Two-Stage Sampling }\end{array}$ & $\begin{array}{c}\text { Non-Probability } \\
\text { Sampling: } \\
\text { Quota Sampling }\end{array}$ \\
\hline $\begin{array}{l}\text { Sample size / Samples of } \\
\text { occupants }\end{array}$ & 19 & 10 \\
\hline $\begin{array}{l}\text { Total sampling } \\
\text { population }\end{array}$ & & 190 \\
\hline
\end{tabular}

\section{Analytic Network Process}

The development of questionnaire is designed in structured form based on the sustainable business location characteristics of PBO. The data collected in the questionnaires were the opinions from the occupants of $\mathrm{PBO}$ that will be used to determine the level of importance for each characteristic of the sustainable business location of PBO. All the occupants of PBO have different views and perceptions on each characteristic. Therefore, every occupant of PBO will have to decide the suitable and important characteristics in determining the importance level of sustainable business location characteristics for the PBO they occupied.

Instead of determining the priorities of PBO's sustainable business location criteria, ANP relates all the criteria which affect each other and have non-linear interactions in a network. The Fundamental Scale for pairwise comparisons needs to be implemented in determining each sustainable business location characteristics of PBO in the ANP model. With the ANP scale, the answers in the questionnaire were analysed to determine the level of importance for each characteristic of PBO in the research area. The ANP Scale in determining the pairwise comparisons for each characteristics of PBO is presented in Table 2.

Table 2: ANP scale to determine the weightage of sustainable business location characteristics of PBO

\begin{tabular}{cc}
\hline \multicolumn{2}{c}{ The Fundamental Scale for Pairwise Comparison } \\
\hline Intensity of Importance & Verbal scale \\
\hline 1 & Equal importance \\
3 & Moderate importance \\
5 & Strong importance \\
7 & Very strong importance \\
9 & Extreme importance \\
$2,4,6,8$ & Intermediate values \\
\hline Source: Saaty (1980) \& Saaty (1996)
\end{tabular}


Heng Jia Yun, Edie Ezwan Mohd Safian \& Ahmad Kaseri Ramin

Sustainable Business Location Characteristics of Purpose-Built Offices in Malaysia

The ANP method was applied to this objective to access the pairwise comparison for each sustainable business location characteristic for the evaluation of the PBO performance in Malaysia. All the pairwise comparisons were evaluated through the comparisons between two characteristics to determine the weight of dependence for each characteristic. However, the ratio scale priority vectors in the ANP that derived from pairwise comparison matrices are not synthesized linearly (Sadeghi, Rashidzadeh, \& Soukhakian, 2012). Figure 1 illustrates on how the pairwise comparison for each sustainable business location characteristic of $\mathrm{PBO}$.

\begin{tabular}{|c|c|c|c|c|c|c|c|c|c|c|c|c|c|c|c|c|c|c|}
\hline Characteristics & \multicolumn{6}{|c|}{$\longleftarrow$} & \multicolumn{5}{|c|}{ Weightage } & \multicolumn{6}{|c|}{$\longrightarrow$} & Characteristics \\
\hline $\begin{array}{c}\text { Location of } \\
\text { commercial feature }\end{array}$ & 9 & 8 & 7 & 6 & 5 & 4 & 3 & 2 & 1 & 2 & 3 & 4 & 5 & 6 & 7 & 8 & 9 & $\begin{array}{l}\text { Availability of } \\
\text { ansport options }\end{array}$ \\
\hline $\begin{array}{c}\text { Location of } \\
\text { commercial feature }\end{array}$ & 9 & 8 & 7 & 6 & 5 & 4 & 3 & 2 & 1 & 2 & 3 & 4 & 5 & 6 & 7 & 8 & 9 & \\
\hline $\begin{array}{c}\text { Location of } \\
\text { commercial feature }\end{array}$ & 9 & 8 & 7 & 6 & 5 & 4 & 3 & 2 & 1 & 2 & 3 & 4 & 5 & 6 & 7 & 8 & 9 & 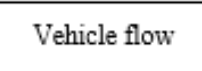 \\
\hline $\begin{array}{r}\text { Locat } \\
\text { commerci }\end{array}$ & 9 & 8 & 7 & 6 & 5 & 4 & 3 & 2 & 1 & 2 & 3 & & 5 & 6 & 7 & 8 & 9 & \\
\hline $\begin{array}{r}\text { Availa } \\
\text { transpor }\end{array}$ & 9 & 8 & 7 & 6 & 5 & 4 & 3 & 2 & 1 & 2 & 3 & & 5 & 6 & 7 & 8 & 0 & $\begin{array}{l}\text { Transportation } \\
\text { distance }\end{array}$ \\
\hline $\begin{array}{l}\text { Availability of } \\
\text { transport options }\end{array}$ & 9 & 8 & 7 & 6 & 5 & 4 & 3 & 2 & 1 & 2 & 3 & & 5 & 6 & 7 & 8 & 9 & $w$ \\
\hline $\begin{array}{l}\text { Availab } \\
\text { transport }\end{array}$ & 9 & 8 & 7 & 6 & 5 & 4 & 3 & 2 & 1 & 2 & 3 & & 5 & 6 & 7 & 8 & 9 & $\begin{array}{l}\text { Efficiency of } \\
\text { property market }\end{array}$ \\
\hline $\begin{array}{l}\text { Transportation } \\
\text { distance }\end{array}$ & 9 & 8 & 7 & 0 & 5 & ${ }^{4}$ & 3 & 2 & 1 & 2 & 3 & & 5 & 6 & 7 & 0 & 9 & venicle flow \\
\hline $\begin{array}{l}\text { Transportation } \\
\text { distance }\end{array}$ & 9 & 8 & 7 & 0 & 5 & 4 & 3 & 2 & 1 & 2 & 3 & 7 & 5 & 6 & 7 & 8 & 9 & $\begin{array}{l}\text { ency of } \\
\text { market }\end{array}$ \\
\hline Vehicle flow & 9 & 8 & 7 & 0 & 5 & 4 & 3 & 2 & 1 & 2 & 3 & & 5 & 6 & 7 & 8 & 9 & $\begin{array}{c}\text { Efficiency of } \\
\text { property market }\end{array}$ \\
\hline
\end{tabular}

Figure 1: Weightage diagram of sustainable business location characteristics

In the questionnaire, all the counterbalance between sustainable business location characteristics of $\mathrm{PBO}$ were evaluated using the pairwise comparison between two characteristics to obtain the dependence of the particular characteristic. In determining the weight of dependence of each sustainable business location characteristic of PBO, the geometric mean method and ANP method were employed to analyse the data and information obtained in each questionnaire. In this questionnaire survey, Microsoft Excel was used to translate all the data collected by the geometric mean method. The geometric mean obtained for each characteristic of PBO was then applied in the ANP analysis to determine the relative dependence among each other. With the help of ANP software, the weight of dependence of sustainable business location characteristics of PBO was calculated. 


\section{RESULTS AND ANALYSIS}

157 occupants from the selected 19 PBOs responded to the questionnaire-based survey. In this survey, each PBO building was evaluated for the weight of sustainable business location characteristics using ANP approach. Data were compiled and analysed based on main streets selected.

Table 3 presented the dependence of each characteristic that have been indicated by the preferences of stakeholders towards sustainable business location of $\mathrm{PBO}$.

Table 3: Overall mean weightage of sustainable business location characteristics

\begin{tabular}{|c|c|c|c|c|c|}
\hline \multirow[b]{2}{*}{ Characteristics } & \multicolumn{4}{|c|}{ Mean weightage } & \multirow[b]{2}{*}{$\begin{array}{c}\text { Overall } \\
\text { mean } \\
\text { weightage }\end{array}$} \\
\hline & Jalan Ampang & $\begin{array}{c}\text { Jalan } \\
\text { Sultan } \\
\text { Ismail }\end{array}$ & $\begin{array}{c}\text { Jalan Raja } \\
\text { Chulan }\end{array}$ & Jalan Imbi & \\
\hline $\begin{array}{l}\text { Location of } \\
\text { commercial } \\
\text { feature }\end{array}$ & 5.4 & 8.1 & 7.9 & 9.1 & 7.6 \\
\hline $\begin{array}{l}\text { Availability of } \\
\text { transport options }\end{array}$ & 13.5 & 13.5 & 10.8 & 11.7 & 12.4 \\
\hline $\begin{array}{l}\text { Transportation } \\
\text { distance }\end{array}$ & 12.1 & 11.6 & 9.1 & 11.0 & 11.0 \\
\hline Vehicle flow & 12.9 & 8.6 & 10.9 & 7.4 & 10.0 \\
\hline $\begin{array}{l}\text { Efficiency of } \\
\text { property market }\end{array}$ & 11.0 & 10.3 & 14.4 & 11.4 & 11.8 \\
\hline $\begin{array}{l}\text { Image/Branding } \\
\text { of location }\end{array}$ & 11.8 & 11.8 & 12.0 & 7.9 & 10.9 \\
\hline $\begin{array}{l}\text { Access to } \\
\text { amenities }\end{array}$ & 11.8 & 7.9 & 10.1 & 9.9 & 9.9 \\
\hline $\begin{array}{l}\text { Access to public } \\
\text { transportation } \\
\text { and terminal }\end{array}$ & 14.3 & 18.2 & 11.8 & 15.8 & 15.0 \\
\hline Access to market & 7.2 & 9.9 & 13.0 & 15.8 & 11.5 \\
\hline
\end{tabular}

Based on Table 3, in overall, the access to public transportation and terminal characteristic was favourable for occupants of PBO since it has the highest overall mean percentage whereby it has recorded the weight of dependence of $14.3 \%$ for Jalan Ampang, $18.2 \%$ for Jalan Sultan Ismail, 11.8\% for Jalan Raja Chulan and $15.8 \%$ for Jalan Imbi. The findings also show that the characteristics of availability of transport options, efficiency of property market, and access to public transportation and terminal were on average level where the percentage of weight of dependence has recorded above $10 \%$ for all the streets. Nevertheless, the characteristic of efficiency of property market has gained the highest percentage of weight of dependence, which was $14.4 \%$ for Jalan Raja Chulan. The weight of dependence of the availability of transport options, 
Heng Jia Yun, Edie Ezwan Mohd Safian \& Ahmad Kaseri Ramin

Sustainable Business Location Characteristics of Purpose-Built Offices in Malaysia

transportation distance, vehicle flow, efficiency of property market, image/branding of location, access to amenities and access to market characteristics were average, around $7.2 \%$ to $15.8 \%$. For Jalan Imbi, the access to market characteristic has ranked the highest in the percentage of weight of dependence where it gained the percentage of $15.8 \%$ as much as the access to public transportation and terminal characteristic for the same street. However, the location of commercial feature characteristic has the least overall mean weightage along Jalan Ampang, Jalan Sultan Ismail, Jalan Raja Chulan and Jalan Imbi at $5.4 \%, 8.1 \%, 7.9 \%$ and $9.1 \%$, respectively.

Based on the findings, it is proven that the characteristic of access to public transportation and terminal was chosen by most of the respondents compared to other main characteristics since they prefer to have easy access to their workplaces by public transportation. On the other hand, the location of commercial feature characteristic was not favoured by the respondents for all four streets because most of commercial landmarks, PBO buildings and commercial buildings are located in Kuala Lumpur Golden Triangle areas.

\section{CONCLUSION}

The ANP analysis conducted presents the weight of dependence of each sustainable business location characteristic for PBO. In determining the weight of dependence of each characteristic, the perceptions of stakeholders are useful in order to achieve the aim of this paper. The analysis revealed that the weight of dependence of locational characteristics of $\mathrm{PBO}$ from the perceptions of stakeholders. Through the application of ANP approach, the findings obtained have distinguished this research from the previous studies in which the interdependency among each characteristic in the sustainable business location model of PBO has measured. A further study is required to develop a location factor matrix in order to improve the Malaysian PBO market.

\section{ACKNOWLEDGEMENT}

This research was funded by the Fundamental Research Grant Scheme (FRGS) Vot:1633 managed by the Research Management Centre (RMC) UTHM .

\section{REFERENCES}

Adnan, Y. M., Daud, M. N., Ahmad, I., \& Aziz, A. (2009). Determining the criteria for the classification of purpose built office buildings in Malaysia. Pacific Rim Property Research Journal, 15(2), 225-243.

Ahmed, S. (2009). Methods in sample surveys. (n.p.): The Johns Hopkins University.

C H Williams Talhar \& Wong (2015). Property market 2015.

Dong-mei, Q., \& Chun-shu, F. (2011, September). Study on network security assessment based on analytical hierarchy process. International Conference on Electronics, Communications and Control. September 9-11, 2011, Ningbo, China. 
Journal of the Malaysia Institute of Planners (2019)

Ishizaka, A., \& Nemery, P. (2013). Multi-criteria decision analysis: Methods and software (First Edition). Chichester: Wiley.

Saaty, T. L. (1980). The analytic hierarchy process. New York: McGraw-Hill

Saaty, T. L. (1996). The Analytic Network Process. Pittsburgh: RWS Publications.

Saaty, T. L. (2009). Theory and applications of the analytic network process: Decision making with benefits, opportunities, costs and risks. Pittsburgh: RWS Publications.

Sadeghi, M., Rashidzadeh, M. A., \& Soukhakian, M. A. (2012). Using analytic network process in a group decision-making for supplier selection. INFORMATICA, 23(4), 621-243.

Safian, E. M., \& Nawawi, A. H. (2012, April). Combining AHP with GIS in the evaluation of locational characteristics quality for purpose-built offices in Malaysia. 6th International Real Estate Research Symposium (IRERS). April 24-25, 2012, Selangor, Malaysia

Taslicali, A. K., \& Ercan, S. (2006). The analytic hierarchy \& the analytic network processes in multicriteria decision making: A comparative study. Journal of Aeronautics and Space Technologies, 2(4), 55-65.

Received: $28^{\text {th }}$ October 2018. Accepted: $1^{\text {st }}$ March 2019 